\title{
Challenges and prospects of partnership among local and foreign Christian missionaries in Nigeria
}

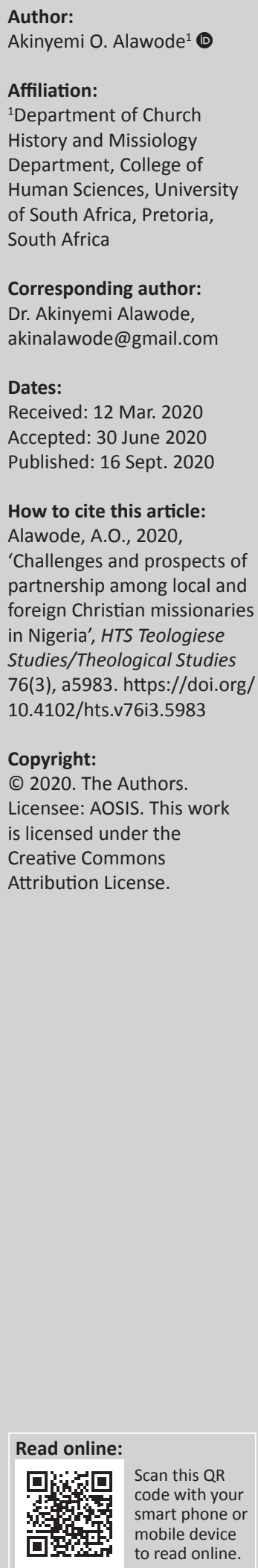

Scan this QR code with your smart phone or mobile device to read online.

The subject of partnership is one that is receiving attention in different spheres of life today. Businesses are seeking to expand by bringing together different specialisations to complement each other. All these grew out of a desire to have better output. The Christian missions' enterprise should not be an exception in the quest for better performance; hence, the need to explore the opportunity of partnership for the expansion of God's kingdom. This article researched how foreign and local mission agencies could develop an effective partnership in Christian missions. The article considered the concept of partnership, the biblical basis for partnership, the historical development of the partnership, the importance of partnership in the 21st century, the prospect of partnership in the 21st century, challenges of partnership in the 21st century and finally, how both local and foreign mission agencies could build an effective, efficient and dynamics partnership mission project before the conclusion of the 21st century.

Keywords: partnership; Christian missions; advancement; God's kingdom; challenges of partnership.

\section{Introduction}

Though the partnership is not an entirely new concept in Christian missions, there is a need to look at it again because every era of history has its peculiarities. Therefore, the author seeks to examine partnership in the context of Christian missions in the 21st century. Firstly, the concept of partnership in general will be discussed, followed by the biblical basis for partnership in Christian missions, a brief historical perspective of partnership in Christian missions, the importance of partnership in 21st-century Christian missions and finally, the challenges and prospects of partnership in 21st-century Christian missions.

The researcher puts into consideration what 'partnership' means and how various mission agencies, both local and foreign, understood it in the 21st century; the author draws his conclusions about the theology of mission partnerships from a missiological reading from the book of Ephesians 4:2-7. Considering Paul's emphasis on the passage, the researcher believes that Jesus Christ is the foundation of the church's oneness. So various Christian mission agencies are called to work together, partner together and collaborate for world evangelisation, serving one another in love and humility according to the word of God, and bringing into the partnership the exceptional gifts that the different mission agencies have received from God, to equip the saints until all of us grow in the fullness of Christ.

\section{The concept of partnership}

A partnership is related to the coming together of two or more entities for a common goal. It is a concept used in a wide variety of domains in life, ranging from marriage to the business world as expressed in popular terms like 'life partner' or 'business partner' (Murray 2019:1).

A partnership is a relationship of complementarity. Going back to the account of creation, God declared that it was not suitable for Adam to stay alone, so he created a helper for him, a companion who was like him. The import is that a woman as a life partner to a man was to complement him. The researcher believes that a partnership is, therefore, a relationship in which separate entities come together to fill the gaps in each other's lives.

Further understanding of the concept of partnership can be gained from its use in the business world. A partnership is a form of business establishment defined as 'a legal method of corporate business among people who share management and profit' (Murray 2019:1). Thus, the partnership 
has to do with the sharing of both the responsibility and the turnover of a business, and this is essential because it gives the business access to additional resources such as new ideas, expertise, products and services (Novello 2019:3). In business, partners pool their money together for a common goal; they share skills and resources and profit and loss.

The partnership is a relationship that revolves around an objective, where separate entities join hands together, collectively using their resources to carry out a project in a better way than any of them can do independently. Djao captured this notion well as cited by Andre Abah (2003), who states that partnership is:

[W] hen there is a close working relationship between individuals and organisations, who agreed to work together as a team for a specific purpose because they can achieve more together than by themselves individually. (pp. 2, 154)

Such 'working relationships' are essential not only in marriage or business but also in Christian ministry in general and Christian missions in particular.

\section{Biblical basis for partnership in Christian missions}

Though the term 'partnership' may not be reflected in every version of the Bible, its idea abounds. The scripture is replete with accounts of God's people working together to achieve goals. Thus, partnership is reflected in unity and teamwork. In the opinion of Odesola (2018:17), biblical backing for partnership is in passages that encourage unity and generosity. A typical example of unity and teamwork in the Old Testament is in the Israelites' battle against the Amalekites. The Israelites' victory took the cooperative efforts of Moses, Aaron and Hur on the mountain and those of Joshua and the Israelite army on the battlefield. In the New Testament, an outstanding example is the ministry of Jesus Christ. Ayokunle, in an interview with Ayandokun (2013:31), insists that Jesus, in his ministry with his disciples, exemplifies partnership, teamwork and interdependence.

Moreover, scripture teaches the mutual dependence of the believers, pointing to the fact that Christians are to complement one another. The metaphor of the church as a body as we have it in 1 Corinthians 12 depicts the interdependence of the different parts. The fact that the body is composed of different parts making up a unified whole implies that no member can stand alone. Thus, God designed the church such that members play complementary roles. Ayandokun (2013:31), corroborating this idea, states that individuals and churches contribute diverse strengths to complement one another. He went further to relate this to missions and evangelism by stating that 'individual members need one another to complement in order to carry out and realise the task of global evangelism and missions' (Ayandokun 2013:31). This article tries as much as possible to address the danger of lack of cooperation among mission agencies both local and international because if they are unable to come into agreement on their mission efforts, it will be difficult if not impossible to fulfil God's mandate on Earth.

Furthermore, partnership in the Bible takes the form of fellowship and sharing. According to Cueva (2007:274), the New Testament word that most closely relates to the idea of partnership is koinonia. Explaining the term, Luis Bush (1990:23-24) states that koinonia is a term used to describe a relationship such as a marriage or business agreement, where both privileges and responsibilities are shared. Therefore, passages that refer to fellowship and sharing call attention to partnership in ministry. These include 2 Corinthians 9:14, which talks about sharing in prayers, and 2 Corinthians 9:8-10, which mentions sharing resources. An excellent biblical example of partnership in terms of koinonia is the relationship between Paul and the Philippian church (Phlp 1:3-5), which is centred around the goal of advancing the gospel.

Moreover, partnership is characterised by the sharing of material possessions; the Philippians send a gift to Paul. Furthermore, they share information; Paul is excited to report to them how his imprisonment has led to the advancement of the gospel. In turn, he wants to know how the gospel is advancing with them; hence, he sends Timothy. They also share each other's burdens, as they always pray for each other (Bush 1990:24-25).

\section{Historical development of partnership in Christian missions}

The partnership has long been a part of Christian missions. However, the form it takes and the emphasis it receives have differed from one epoch to another.

The partnership has been an essential element of Christian missions throughout history, though its understanding, emphasis and forms of expression may differ from time to time. Lawrence Keyes (2003:156-157) identifies three classical forms of partnership in missions, namely, comity agreement - cooperative agreement between entities that belong together historically and cooperation in a loosely structured association. In addition, Abah (2003:159) advocates a fourth kind of partnership, that which is driven by a common goal - that is, the desire to complete a specific task of the Great Commission.

Comity agreement is the kind of partnership where mission agencies that find themselves in the same country agree to divide the field, such that each of them focuses on a geographical location. Goheen and O'Gara (2006:83-91) noted that by the 10th century there was increased zeal for foreign missions among Protestant churches, leading to a new initiative in cooperation and unity. They noted further that comity agreement became necessary because the field to be covered was so vast and the resources were so few. Thus, they agreed to distribute themselves across different 
fields so that two agencies would not occupy the same field. The benefit of this approach was that it checked competition and duplication of effort. Nevertheless, the disadvantage, as pointed out by Warren, cited by Abah (2003:3), is that it leads to sectarianism, where one geographical region belongs to just one denomination. It may discourage fellowship with brethren across nearby geographical regions.

Then there is the cooperative agreement between entities that belong together historically. Notable is the cooperation between missions and the national churches that developed from their efforts. The development of such a partnership did not come easily, as revealed in the stages and processes leading to it. In the early periods, Christian missions had a colonial outlook. Paternalism was the order of the day. The missionaries were the masters; they dictated what the natives could do. The missionaries supplied the funds. Citing Pierce, Luis Bush (1990:36) states that 'all missionaries were colonialist and paternalistic to the end of the 10th century'. He pointed out that Africans were viewed as inferior to white people and thus considered incapable of producing leadership. In this period, missionaries were thinking for the natives, purportedly to protect them and guide them to maturity (Bush 1990:36). The quest for independence and freedom to decide their direction was increasing by the 20th century. The Second World War was a factor that fostered such independence. Missionaries left the field, putting leadership into the hands of the nationals. When the war ended, the nationals clamoured for greater freedom, and this led to tension between the national church and white missionaries (Bush 1990:36-37). Four different theories were proposed to resolve this tension (Steffen 2000:17). One of them is departure, where the missionary turns over the work to the nationals and moves out, considering his or her work over. Another model is subordination, where the missionaries work under the national church. There is also the theory of parallelism, where each party develops their separate agenda. Finally, there is the partnership model, where the church and mission work alongside each other as equal partners. An example is the cooperation between Sudan Interior Mission (SIM) and Evangelical Church Winning All (ECWA) in Nigeria. The church determines where the ministry needs are, and they request the missionary to fill them (Bush 1990:27).

Moreover, there is a partnership as cooperation between members of one loosely structured association, and this is a kind of Christian intergroup or interdenominational cooperation, such as the International Missionary Council, Lausanne Committee for World Evangelization, World Evangelical Alliance or the Association of Evangelicals of Africa, which owns the Nairobi Evangelical Graduate School of Theology (Abah 2003:15).

While recognising all these forms of partnership, the researcher agrees with Abah's position that the kind of partnership needed today is one that is driven by a common desire to complete the specific task of the Great
Commission (Abah 2003:15). In other words, what should matter in partnership today is not the origins of the different partners or their previous relationship, but the goal for which they come together as partners. This point is corroborated by Tom Steffen (2000:2) when he states that 'strategic partnerships today go far beyond mission agencies and national churches ... participants may come from anywhere in the world and go anywhere in the world'.

\section{Importance of partnership in 21st-century Christian missions}

The importance of partnership in missions is overwhelming. Going by the meaning and biblical basis for partnership, it is evident that the best approach to the task of the Great Commission is by a collective effort of the body of Christ. It has become evident that the task is beyond the capacity of any individual church or agency. A statement credited to Tokunbo Adeyemo brings out the point very clearly. $\mathrm{He}$ states that (Bush 1990):

$[N]$ o single group - regardless of how skilled, gifted, experienced or rich - can finish the task of world evangelisation alone. It will take all the true Christian churches and parachurch organisations all over the world working together in obedience to Christ. (p. 43)

Hence, to achieve the maximum in our mission fields, Christians must pool their resources together, complementing each other's skills, gifts and experiences.

The previous assertion on the necessity of partnership cannot be more accurate than in the 21st century. The peculiar nature of 21st-century missions makes the partnership a much more pressing necessity. Brien O'Connell (2017:1) cites an anonymous mission chief executive officer as stating that the fresh challenges posed by the mission enterprise today are more complex than ever before, thereby making partnership indispensable.

Christian missions in the 21st century broke away from the traditional understanding, having their peculiar characteristics. Today, the young generation of the Western church lack the zeal and enthusiasm that characterised earlier generations, and so they do not easily make a long-term commitment to missions; this makes short-term missions much more relevant, as they can serve to motivate youth when they get exposed to the realities in the mission field (Blöcher 2019:1).

Furthermore, in this generation, based on the researcher's personal experience in the mission field, many churches are becoming more aware of their roles in Christian missions. They are no longer satisfied to pray and send their money through mission agencies any longer; they desire a level of direct involvement. They want to make a direct impact on the mission field. Moreover, many countries now have a Christian presence and influential national church leaders, such that missionaries are hardly pioneers; instead, they are guest workers who labour mostly in cooperation with the national leaders. 
The task of Christian missions is no longer limited to the Western church. Nor can the newer senders lay exclusive claim to it. The way to make progress in this era is to have partnerships that cut across continents. Without this, much cannot be achieved in missions. Frazer, cited by Bush (1990:45), emphasises the need to embrace it. He warns that 'if we do not have a partnership in Christian missions, we are bound to have poverty of mission in the future'. Bush, therefore, opines that partnership in missions, though risky, is worth it. His position is that the West must partner with Two-Third World churches or become ineffective in the world (Bush 1990:45). Moreover, O'Connell (2017:1) says the ability to partner with others is one of the critical things that reveal the excellence of an organisation in the 21st century.

\section{The prospect of partnership in 21st-century missions}

Despite the difficulties, there are reasons to expect that partnership in missions will continue to thrive in the 21st century. There are good prospects for partnership.

The increasing number of Two-Third World missionaries in the 21st century gives a good prospect for partnership. One striking feature of Christian missions in the 21st century is the increase in the number of missionaries from countries of the Southern Hemisphere, which were traditionally recipients of missionaries before. Missionaries from these countries make up half of the global mission force (Blöcher 2019:1). These countries send out their missionaries with great enthusiasm and support them financially with great sacrifices. They include Brazil, Korea and Nigeria, among many others. For example, based on the researcher's experience, the Global Missions Board of Nigeria Baptist Convention sent missionaries to countries like the Republic of Benin, Togo, Niger and Mali.

On the contrary, older missionary-sending countries are becoming weak in their zeal, and this means that the continuous relevance of Western countries in Christian missions depends on their ability to partner with these new senders, which gives hope of more partnership. In the words of Luis Bush (1990:31), 'as two-third world missions continue to grow, we will see an increasing variety of creative financial partnerships develop with their roots right in the Pauline letters'.

Moreover, the communal orientation of these missionaries from the Southern Hemisphere is a factor that opens them up for readiness to partner (Blöcher 2019:1).

Secondly, technological advancement in the 21st century is creating more opportunities for partnership. The 21st century is an information age, in which partnership in mission has virtually become 'information exchange' (Bush 1990:57). Dissemination of information is more accessible and very fast with the use of the Internet, and this makes Christian mission enterprises carried out in different parts of the world easily visible. It also serves as the meeting point for prospective partners.
Furthermore, the increasing efforts of international mission conferences make partnership more practicable. Such conferences have encouraged unity and provided a forum where people from different backgrounds within the body of Christ can air their opinions. They also provide an opportunity for mutual respect among different Christian groups. In this regard, Bush (1990:42) notes that 'intergenerational partnership is emerging, with young leaders respecting the wisdom and experience of the older; and older leaders rejoicing in the creative leadership of young leaders'. He goes further to express optimism about the future of partnership by alluding to activities of the Congress on World Evangelism. Here, leaders of Third-World churches, as well as Western churches, charismatics and non-charismatics, develop a good relationship in world evangelisation (Bush 1990:42). Of relevance here is Article 8 of the Lausanne Covenant, which gives a good prospect for partnership by recognising the increasing prominence of younger churches. It reads in part: 'God is raising the younger churches a great new resource for world evangelisation ... thus, an increasing partnership of churches will develop' (Winter 2009:766).

\section{Challenges of partnership in 21st-century Christian missions}

As crucial as the partnership is, it is not easy to develop. Challenges are militating against it, some of which the author has discussed. Some factors have always posed a challenge to partnership in every generation, while others arise from the peculiar nature of 21st-century missions.

The tendency to dominate is a leading challenge to the partnership. Each partner brings some form of resources into the relationship but not in equal proportion. Odesola (2018:35), citing Christopher R. Little, rightly notes that the partner with the more highly priced resources tends to dominate the others. In most cases, they draw out the conditions for others in such a partnership. According to Little, the danger manifests in the imposition of the views of the wealthier partner onto others (Odesola 2018:35). In reaction to this, the partner with fewer resources, feeling undermined, either refrains from the partnership or accepts a less active role. Neither of these options is healthy for Christian missions. Luis Bush, relating this challenge to the partnership between Western and Two-Third World churches, observes that churches in the West are more affluent than the other churches, thereby creating in them a donor mentality. This mentality has made them assume the role of the financier of the national church, thus undermining the role of the national church in decision-making (Bush 1990:3). In other words, the West has a more prominent voice.

Closely related to this challenge is the tendency to dependence. Bush observes that churches with fewer resources who have enjoyed financial help from the West often do not want to leave this security. They desire to be continually spoon-fed rather than rise to their responsibility 
(Bush 1990). This attitude is also not healthy for partnerships because when one party enters a partnership only to receive from the other, such a relationship will not last. In this regard, Odesola (2018:35) maintains that when only one party is committed to the partnership, it cannot be enough.

Inordinate emphasis on the self-theory is another factor that poses a difficulty for partnership in 21st-century Christian missions. The three self-theories of self-supporting, selfpropagating and self-governing, as proposed by Henry Venn, are to free the national churches from their dependence on the West. When applied, they create a sense of responsibility in the nationals. However, the disadvantage is that it keeps them focused on themselves, as if the work is theirs and others should not share the glory.

On the contrary, it tends to make donors look away entirely from nationals that may have genuine needs (Bush 1990:3).

Another problem that militates against effective partnership is doctrinal differences. There are diverse doctrinal beliefs and emphases within the body of Christ today. This diversity can hinder an effective partnership. In the 21st century, there is a sharp difference in doctrinal beliefs and practices between churches and denominations, and this threatens the ability to collaborate even among Christian groups that have a historical relationship. For instance, the Church of Nigeria (Anglican Communion) has threatened to cut off fellowship with the Church of England based on the stance of the latter on gay marriage.

Furthermore, the uncoordinated zeal of local churches poses a challenge to the partnership. The 21st-century local churches desire more direct involvement in missions. This zeal has led many churches to carry out mission work at a high cost. They support such work with great enthusiasm because they consider it their own. However, this poses a challenge to partnership in that such churches find it difficult to cooperate with others because they do not want to lose a sense of ownership or control of such work. Furthermore, this has led to duplication of effort and slowed down the overall missionary effort.

\section{Building effective partnership in 21st-century Christian missions}

Having considered the essential nature of partnership in 21st-century missions and after understanding the challenges associated with it, it is crucial to know how to go about developing effective partnership in missions. Odesola (2018:31) gives insight and presents some principles of an effective partnership. Furthermore, Luis Bush gives helpful insight into the subject matter (Bush 1990:46-47). Their ideas form the basis of the discussion that follows.

In the first place, a functioning partnership requires a clear focus; the goal must be well defined. Partners must agree on this goal and must work towards achieving it, rather than pursuing their projects (Bush 1990). In other words, everything to be done in the partnership will be for the achievement of the mutual goal.

Then there is a need for an attitude of equality. Equality has to do with the value partners accord each other. It has to do with appreciating what each partner brings into the relationship. Indeed, all partners do not have the same level of resources, yet they can develop respect for each other. Partners who are rich in financial resources must recognise that others are rich in other areas, and this then gives no room for a superiority complex. The partners should listen to each other and respect, trust and learn from each other. Just like in marriage, partners in ministry must see each other as being equal before God while differing in nature and function (Bush 1990).

Furthermore, in an active partnership, there must be doctrinal compatibility. Partners must understand each other's doctrinal position and determine whether they can work together. Bush (1990) alludes to the fact that partners may not be able to agree on all points of doctrinal beliefs. However, they must agree on essentials; that is, all partners must as a matter of necessity hold onto those doctrines that are tied inextricably to the gospel.

Finally, partners must operate on trust and accountability. Because the partnership involves money, there must be transparency to trust each other (Bush 1990).

\section{Conclusion}

The subject of partnership is very relevant in Christian missions. The partnership has its roots in the scriptures. It is also needful for the advancement of the gospel, as it results in higher output. Moreover, the peculiarities of 21st-century Christian missions present some challenges to the partnership, but they also offer some prospects. Therefore, practitioners in Christian missions must seize the opportunities afforded by 21st-century mission trends to develop a partnership in Christian missions. This article proposed how foreign and local mission agencies could advance Christian missions through a partnership. It is appropriate for both local and foreign missionaries to go into partnership because it will enhance our mission efforts by making it possible for us to reach the unreached and the unengaged, both far and near. The partnership discussed in this article would afford us the opportunity of working together as one body in Christ Jesus. The article identified some of the challenges confronting Christian mission partnership arrangements - the dominance tendency, dependence tendency, inordinate emphasis on the self-theory and finally doctrinal differences.

However, some recommendations were given that will help in overcoming those challenges. According to the researcher, partnership arrangements should have a clear focus; both parties should avoid an attitude of superiority towards one another because we are equal before God; 
doctrinal compatibility should be considered; and finally, all partners should operate on trust and accountability because this will tell on our individual and organisational integrity.

\section{Acknowledgements}

I wish to express my gratitude to the Lord, my creator for his grace upon my life, also I appreciate my wife and my children, Mrs Oluwatoyin Wumi Alawode, Peace, Praise and Precious for their support when I was away in United States of America.

\section{Competing interests}

The author declared that no competing interest exists.

\section{Author's contributions}

A.O.A. is the sole author of this article.

\section{Ethical consideration}

This article followed all ethical standards for a research without direct contact with human or animal subjects.

\section{Funding information}

The research received no specific grant from any funding agency in public, commercial or not-for-profit sectors.

\section{Data availability statement}

Data sharing is not applicable to this article as no new data were created or analysed in this study.

\section{Disclaimer}

The views and opinions expressed in this articles are those of the author and do not necessarily reflect the official policy or position of any affiliated agency of the author.

\section{References}

Abah, A., 2003, Strategic partnership in African missions, Missionafric, Pennsylvania, USA Ayandokun, A., 2013, Partnership in missions: Expediting world Evangelisation through partnership in missions, Glory Line Christian Publications, Lagos.

Blöcher, D., 2018, World mission in the 21st century: 12 modern trends, viewed 11 April 2019, from www.dmgint.de.

Bush, L., \& Lorry, L., 1990, Partnering in ministry: The direction of world Evangelism Intervarsity Press, Downers Grove, IL.

Cueva, S., 2007, 'Partnership', in J. Corie (ed.), Dictionary of mission theology: Evangelical foundations, pp. 33-37, Intervarsity Press, Nottingham.

Goheen, M.W. \& O'Gara, M. (eds.), 2006, University Press of America, Lanham, MA

Murray, J., 2019, What is a partnership? How does it work? viewed 01 March 2020, from www.thebalancesmb.com.

Novello, S., 2019, 6 Reasons why strategic partnerships are important for business, viewed 10 March 2020, from https://partners2grow.com.

O'Connell, B., 2017, 'Getting past the myths of partnering', Mission frontiers (March-April 2017), viewed 25 March 2019, from www.missionfrontiers.org.

Odesola, A.O., 2018, 'Partnership in missions as a tool for world Evangelization', in M.A. Ogunewu \& A.O. Odesola (eds.), Global Evangelisation and the challenges for contemporary church, p. 31, Publishing Unit, The Nigerian Baptist Theological Seminary, Ogbomoso.

Steffen, T., 2000, 'Partnership', in S. Moreau (ed.), Evangelical dictionary of world missions, p. 17, Baker Books, Grand Rapids, MI.

Winter R.D., 2009, Perspectives on the World Christian Movement, William Carey Library Publishers, United States. 